PACS: 75.10.Jm, 75.40.Cx

UDC: 538.22

\title{
Low temperature thermodynamics of finite spin-1/2 XX Chain with some distorted links
}

\author{
O.S. Dzhenzherov, E.V. Ezerskaya \\ V. N. Karazin Kharkiv National University, 4 Svoboda sq., Kharkiv, 61022, Ukraine \\ yezerska@karazin.ua
}

ORCID: 0000-0002-6896-9550

DOI:10.26565/2222-5617-2019-31-04

We present the results of our analytical and numerical study of quantum stationary states and the thermodynamics of exactly solvable finite linear spin-1/2 XX chain with one or two distorted links. The exact dispersion equations for the stationary states with one inverted spin for both cases have been derived. The corresponding spectrum consists of one quasi-continuous band and some localized impurity levels. The analytical inequalities for the values of the critical model parameters describing the appearance of local energy impurity levels above and below quasi-continuous band are obtained and analyzed. The field and the temperature dependences of the main thermodynamic characteristics of these models are studied. It is shown, that the appearance of the localized levels near the distorted links may effect significantly on the thermodynamic properties at low temperatures, leading to the additional singularities in the field and the temperature dependences of the principal thermodynamic characteristics. For example, the field dependence of z-projection of average total spin and the field dependence of the magnetization at zero temperature have the finite jumps associated with the quasi-continuous spectrum, and the impurity levels. The remnants of these jumps at rather low temperature are clearly visible. The average z-projections of the spins of distorted link(s) may decrease with the increasing of the magnetic field for some values of model parameters. The temperature dependence of the specific heat may demonstrate additional maxima at very low temperatures. The complex oscillatory pattern of the time dependence of the dynamical longitudinal pair correlation function and the autocorrelation function is associated with the finiteness of the models and the appearance of associated localized energy levels.

Keywords: spin, Heisenberg Hamiltonian, spin-1/2 XX-chain, energy spectrum, thermodynamic characteristics, quantum phase transition.

\section{Низькотемпературна термодинаміка скінченного XX ланцюжка зі спіном $1 / 23$ кількома деформованими взаємодіями}

\section{О.С. Дженжеров, О.В. Сзерська}

Харківський національний університет імені В.Н. Каразіна, м. Свободи 4, 61022, Харків, Украйна

\begin{abstract}
Проведено теоретичне дослідження квантових стаціонарних станів і термодинаміки точно розв'язуваної моделі скінченного лінійного ХХ ланцюжка зі спіном $1 / 2$ з однією або двома двохцентровими ланками з деформованими зв'язками. Отримано точні дисперсійні співвідношення для стаціонарних станів з одним переверненим спіном для обох випадків. Цей спектр складається з однієї квазібезперервної зони і декількох локалізованих домішкових рівнів. Отримано і проаналізовано аналітичні нерівності для значень критичних параметрів моделей, що описують появу локальних енергетичних домішкових рівнів вище і нижче квазібезперервної зони. Досліджено польові і температурні залежності основних термодинамічних характеристик моделей. Показано, що поява локалізованих рівнів поблизу спотворених ланок може мати суттєвий вплив на термодинамічні властивості при низьких температурах, приводячи до додаткових особливостей на польових i температурних залежностях основних термодинамічних характеристик. Наприклад, польова залежність z-проекції середнього повного спина і польова залежність намагніченості при нульовій температурі мають кінцеві скачки, пов’язані як 3 квазінепереривних спектром, так і домішковими рівнями. Залишки цих стрибків добре видно при дуже низьких температурах. Середні значення z-проекції спінів спотвореного зв'язку (зв'язків) можуть зменшуватися зі збільшенням магнітного поля для деяких значень параметрів моделі. Температурна залежність питомої теплоємності може демонструвати додаткові максимуми при дуже низьких температурах. Складний коливальний характер залежності від часу динамічної поздовжньої парної кореляційної функції і автокореляційної функції пов'язані зі скінченністю моделей і 3 виникненням зв'язаних локалізованих рівнів енергії.
\end{abstract}

Ключові слова: спін, гамільтоніан Гейзенберга, XX ланцюжок зі спіном 1/2, енергетичний спектр, термодинамічні характеристики, квантовий фазовий перехід. 


\title{
Низкотемпературная термодинамика конечной XX цепочки со спином $1 / 2$ с несколькими деформированными взаимодействиями
}

\author{
А.С. Дженжеров, Е.В.Езерская \\ Харьковский национальный университет имени В.Н. Каразина, м. Свободы 4, 61022, Харьков, Украина
}

Проведено теоретическое исследование квантовых стационарных состояний и термодинамики точно решаемой конечной линейной XX цепочки со спином $1 / 2$ с одним или двумя двухцентровыми звеньями с деформированными связями. Получены точные дисперсионные соотношения для стационарных состояний с одним перевёрнутым спином для обоих случаев. Этот спектр состоит из одной квазинепрерывной зоны и нескольких локализованных примесных уровней. Получены и проанализированы аналитические неравенства для значений критических параметров моделей, описывающих появление локальных энергетических примесных уровней выше и ниже квазинепрерывной зоны. Исследованы полевые и температурные зависимости основных термодинамических характеристик моделей. Показано, что появление локализованных уровней вблизи искажённых звеньев может оказывать существенное влияние на термодинамические свойства при низких температурах, приводя к дополнительным особенностям на полевых и температурных зависимостях основных термодинамических характеристик. Например, полевая зависимость $z$-проекции среднего полного спина и полевая зависимость намагниченности при нулевой температуре имеют конечные скачки, связанные как с квазинепрерывным спектром, так и примесными уровнями. Остатки этих скачков отчетливо видны при очень низких температурах. Средние значения z-проекции спинов искажённой связи (связей) могут уменьшаться с увеличением магнитного поля для некоторых значений параметров модели. Температурная зависимость удельной теплоёмкости может демонстрировать дополнительные максимумы при очень низких температурах. Сложный колебательный характер зависимости от времени динамической продольной парной корреляционной функции и автокорреляционной функции связаны с конечностью моделей и с возникновением связанных локализованных уровней энергии.

Ключевые слова: спин, гамильтониан Гейзенберга, XX цепочка со спином 1/2, энергетический спектр, термодинамические характеристики, квантовый фазовый переход.

\section{Introduction}

Last decades the discovery of a big number of new compounds with quasi-one-dimensional and quasi-twodimensional magnetic structures has given further impetus to the theoretical studies of low-dimensional systems [1$3]$. In this context the exactly solvable models like spin$1 / 2 \mathrm{XX}$ chain attract much attention of theoreticians [111]. For many years, above chain model was one of the theoretical instruments for checking the numerical results for more general spin systems, and also applied for adequate simulation of the magnetic properties of real compounds [12, 13]. Any real magnetic material has different types of structure defects. The theoretical study of the influence of these defects on the energy spectrum and the thermodynamics of spin chain structures is of interest.

\section{The Hamiltonians}

This work is devoted to the theoretical treatment of the low temperature thermodynamics of some exactly solvable quantum models based on spin-1/2 XX-chain. We study analytically and numerically the finite spin-1/2 $\mathrm{XX}$ chains with defects of different nature: finite linear $\mathrm{XX}$-chain with one and two distorted XX bond.

The corresponding Hamiltonians for these models have the following form

$$
\begin{aligned}
\hat{\mathbf{H}}= & -g \mu_{B} H \sum_{\substack{n=1, n \neq n_{i}, n_{i}+1}}^{N} S_{n}^{z}-J \sum_{n=1 ; n \neq n_{i}}^{N-1}\left(S_{n}^{x} S_{n+1}^{x}+S_{n}^{y} S_{n+1}^{y}\right)- \\
& -\sum_{i}\left[g_{i}\left(S_{n_{i}}^{z}+S_{n_{i}+1}^{z}\right)-J_{i}\left(S_{n_{i}}^{x} S_{n_{i}+1}^{x}+S_{n_{i}}^{y} S_{n_{i}+1}^{y}\right)\right]
\end{aligned}
$$

Here $J, J_{i}>0$ are the exchange integrals for spin-1/2 $\mathrm{XX}$ chain and distorted link(s) respectively, $\mu_{B}$ is the Bohr magneton, $g, g_{i}$ are $g$-factors for the chain $\operatorname{link}(\mathrm{s})$ respectively, $H$ is the longitudinal uniform magnetic field, and $i=1$ or $i=1,2$ for one or two distorted links respectively. Note, that the total "length" of the chain is $N=n_{1}+n_{2}$ for the first case (one distorted link) and $N=n_{1}+n_{2}+n_{3}$ for the second one (two distorted links).

The spin-1/2 XX chain is a well-known example of an exactly solvable spin system (see, for example, [2-4]). Jordan-Wigner transformation [14] reduces (1) to the Hamiltonian of the ideal gas of spinless fermions, so both models are exactly solvable.

\section{Stationary states with one inverted spin}

We diagonalized the Hamiltonian (1) by solving the one particle Schrödinger equation in the lattice site representation and derived the following dispersion relations for the stationary states with one inverted spin

$$
\varepsilon=g \mu_{B} H-\frac{J}{2}\left(x+\frac{1}{x}\right)
$$

for both models and

$$
\left(\beta_{1}-\frac{1-x^{2\left(n_{1}+1\right)}}{1-x^{2 n_{1}}}\right)\left(\beta_{1}-\frac{1-x^{2\left(n_{2}+1\right)}}{1-x^{2 n_{2}}}\right)-\alpha_{1}^{2} x^{2}=0
$$

for $i=1$, and 


$$
\begin{gathered}
\left(\beta_{1} x-\frac{1-x^{2\left(n_{1}+1\right)}}{1-x^{2 n_{1}}}\right)\left(\beta_{1} x-\frac{1-x^{2\left(n_{3}+1\right)}}{1-x^{2 n_{3}}}\right) \times \\
\times\left[\left(\beta_{1} x-\frac{1-x^{2 n_{2}}}{1-x^{2\left(n_{2}-1\right)}}\right)\left(\beta_{2} x-\frac{1-x^{2 n_{2}}}{1-x^{2\left(n_{2}-1\right)}}\right)-\right. \\
\left.-\left(x-\frac{1}{x}\right)^{2}\left(\frac{x^{n_{2}}}{1-x^{2\left(n_{2}-1\right)}}\right)^{2}\right]-\alpha_{1}^{2} x^{2} \times \\
\times\left(\beta_{2} x-\frac{1-x^{2\left(n_{3}+1\right)}}{1-x^{2 n_{3}}}\right)\left(\beta_{2} x-\frac{1-x^{2 n_{2}}}{1-x^{2\left(n_{2}-1\right)}}\right)- \\
\times\left(\beta_{1} x-\frac{1-x^{2 n_{2}}}{1-x^{2\left(n_{2}-1\right)}}\right)-\alpha_{1}^{2} \alpha_{2}^{2} x^{4}=0
\end{gathered}
$$

for $i=1,2$. Here $\alpha_{i}=J_{i} / J, \beta_{i}=\left[2\left(g-g_{i}\right) \mu_{B} H\right] / J$.

The above spectra consist of one quasi-continuous band

$$
\varepsilon=g \mu_{B} H-J \cos k
$$

where $x=\exp (i k)$ is the solutions of (2), (3) with $|x|=1$ , and may have some localized impurity levels, if $x$ is the real number with $|x|<1$. The total number of localized impurity levels is up to two levels and up to four levels for the models with one and two impurity links, respectively. The analytical inequalities for the values of the critical model parameters describing the appearance of the localized energy impurity levels were found for both models. The corresponding formulas for critical values of model parameters are presented below

$$
\left[1+\frac{1}{2}\left(\frac{1}{n_{1}}+\frac{1}{n_{2}}\right) \mp \beta_{\mathrm{c}}\right]^{2}-\alpha_{\mathrm{c}}^{2}=\frac{1}{4}\left(\frac{1}{n_{1}}-\frac{1}{n_{2}}\right)^{2}
$$

for the chain with one distorted link, and

$$
\begin{gathered}
\left(\alpha_{1 c}^{2}+\delta_{1}^{2}-\gamma_{1 c}^{2}\right)\left(\alpha_{2 c}^{2}+\delta_{2}^{2}-\gamma_{2 c}^{2}\right)= \\
=\frac{\left(\alpha_{1 c}-\gamma_{1 c}\right)\left(\alpha_{2 c}-\gamma_{2 c}\right)}{\left(n_{2}-1\right)^{2}} ; \\
\gamma_{1,2 c}= \pm \beta_{1,2 c}-1-\frac{1}{2}\left(\frac{1}{n_{1,3}}+\frac{1}{n_{2}-1}\right) ; \\
\delta_{1,2}=\frac{1}{2}\left(\frac{1}{n_{1,3}}-\frac{1}{n_{2}-1}\right) .
\end{gathered}
$$

for the chain with two distorted links.

\section{Thermodynamics}

Using the dispersion relations (2-4), one can investigate the thermodynamic properties of the models considered. We need only the total number of stationary states and the degeneracy rate of each state for the calculating of the partition function and a several thermodynamic quantities.

We derived the analytical formulas for some principal and local thermodynamic characteristics and studied numerically their field and temperature dependence as the functions of the model parameters.

In particular, we found a complex dependence of the heat capacity on the applied magnetic field with numerous minima and maxima (see fig. 1(a,b)).

We associate the maxima and minima in the weak fields with the quasi- continuous spectra, and the additional extrema in strong magnetic field with the localized levels.

The field dependence of the magnetization and the average value of z-projection $\left\langle S^{z}\right\rangle$ at zero temperature have the finite jumps, which are associated with the transitions of level's energies through zero value.

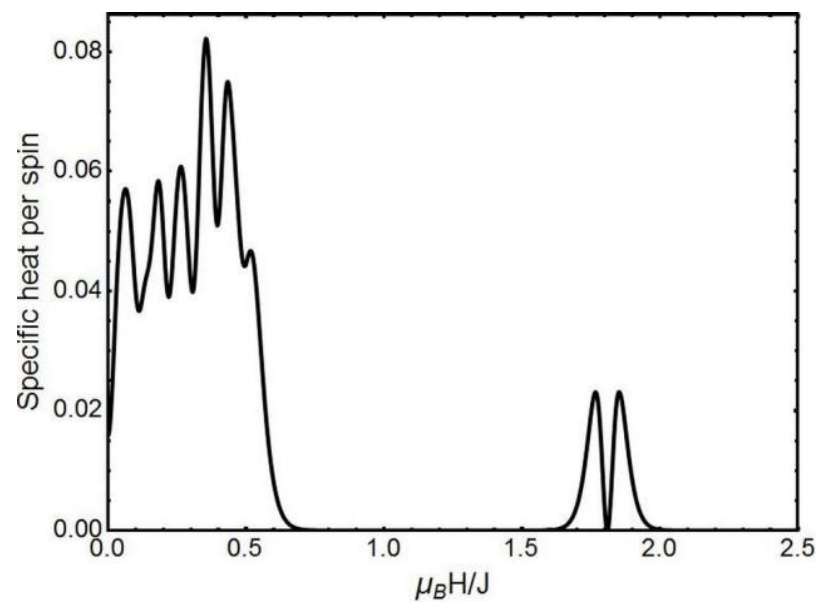

(a)

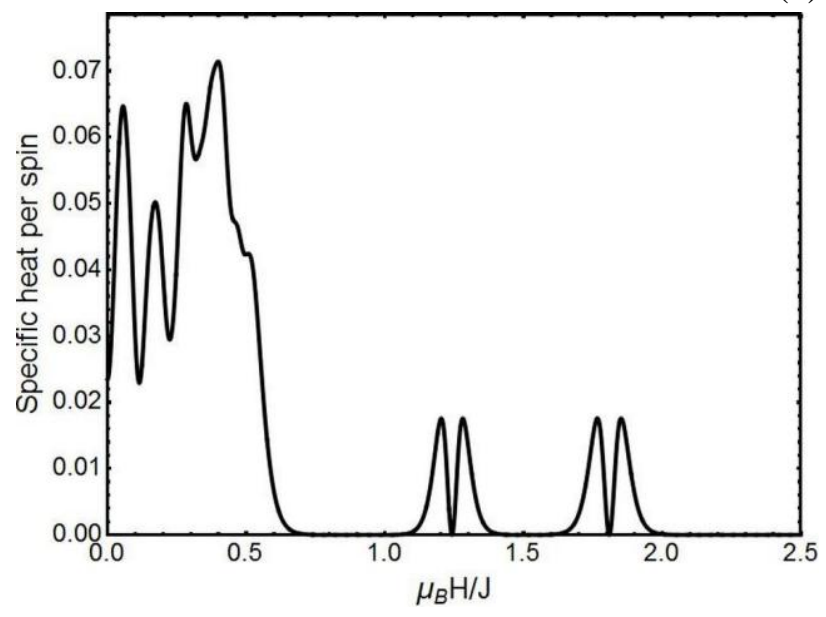

(b)

Fig. 1. Field dependence of specific heat per spin for model with (a) one and (b) two distorted links at $T=0.04 \mathrm{~K}$ with $n_{1}=14, n_{2}=5, \quad n_{3}=6, g=2, \quad g_{1}=2.5, g_{2}=3, J=1 K$, $J_{1}=8 K, J_{2}=6 K$. 
The remnants of these jumps at rather low temperature are clearly visible (see fig. 2). We associate the maxima and minima in weak fields with quasi-continuous spectra, and additional extrema in strong magnetic field correspond to the localized levels.

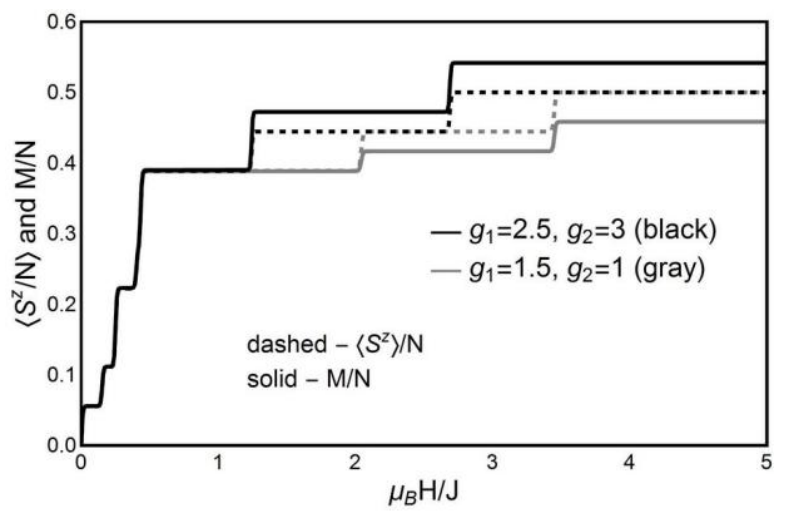

Fig. 2. Field dependence of magnetization and total $\left\langle S^{z}\right\rangle$ per spin for model with two distorted links at $T=0.01 K$ for $n_{1}=n_{2}=n_{3}=6, g=2, J=1 K, J_{1}=12 K, J_{2}=6 K$, and different values of distorted links g-factors

In the case of weak interaction with the main XX chain the field dependence of average value of the spins of distorted link may be decreased and even becomes negative with the increasing of magnetic field, and jumps in the critical field along the direction of the magnetic field (see fig. 3a). Pair correlation function (fig. 3b) is negative for nearest neighbors at zero and weak fields. We associate this behavior with antiferromagnetic character of XX exchange interaction.

The temperature dependence of specific heat per spin for both models with the same number of lattice spins and the same parameters for the first "distortion" at $n_{1}, n_{1}+1$ positions in very weak magnetic field is presented at Fig. 4.

The temperature dependence of the specific heat per spin for the model with one distorted bond (dashed line at fig. 4) has no additional low temperature peaks of XX chains with two distorted links (solid line at fig. 4). The low temperature peaks for the model with two distorted links can be associated with the second "distortion" at $n_{2}, n_{2}+1$ for the model with two links.

The absolute values of longitudinal pair dynamical correlation function and autocorrelation function for the spins of distorted link are pictured at fig. 5. These characteristics also affected noticeably by the local levels, which leads to the complex oscillations pattern, including some kind of beats.

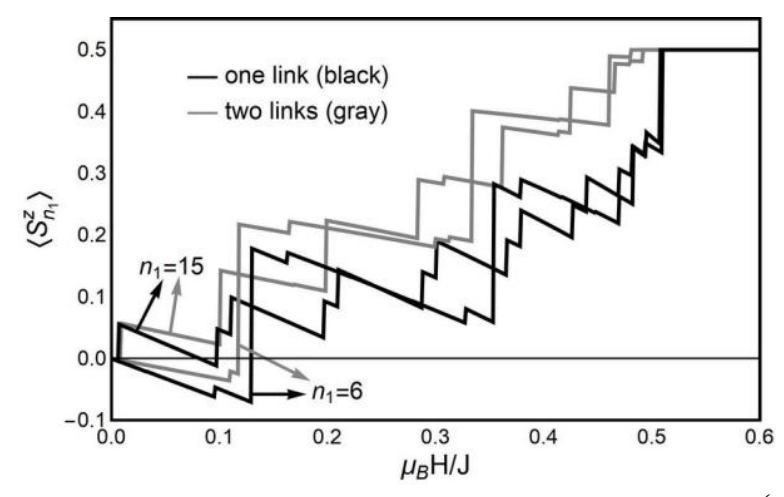

(a)

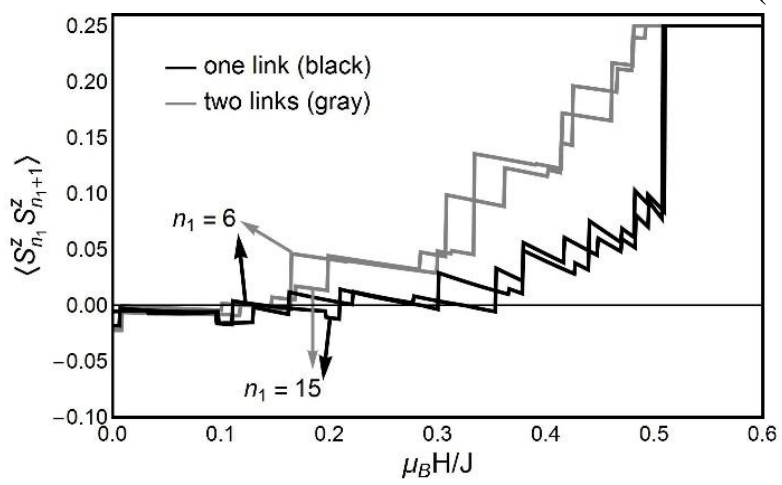

(b)

Fig. 3. Zero temperature field dependence of the average value of $z$-projection of spin (a) and pair correlation function (b) for both models at $J=1 K, J_{1}=0.2 \mathrm{~K}$, $J_{2}=6 K, g=2, g_{1}=1, g_{2}=3$ for two different location of distorted bonds $n_{1}=6,15$ for the chains with total number of spins $N=30$. For the model with two distorted bonds $n_{2}=10, n_{3}=14$ or $n_{3}=5$, respectively.

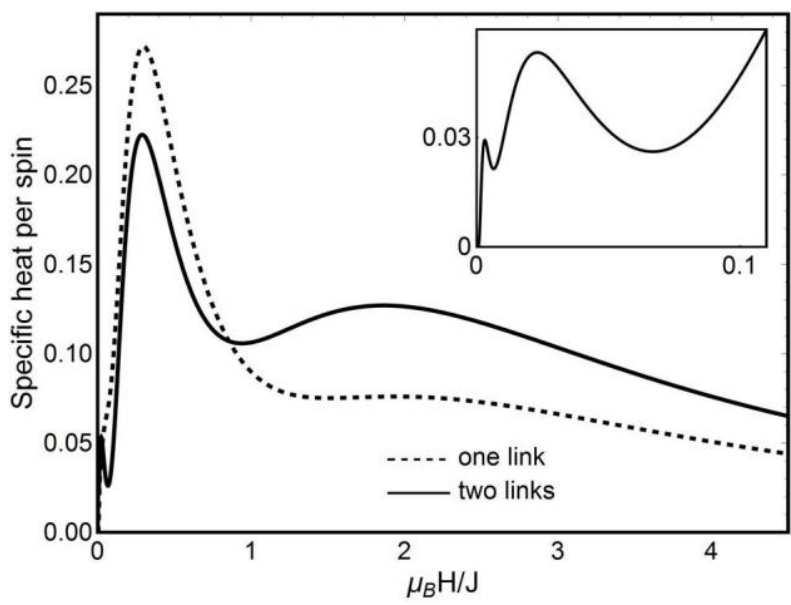

Fig. 4. The specific heat per one spin as a function of temperature for XX chain with one (dashed line) and two distorted links (solid line) for the same total number of spins $\quad N=15$ with $n_{1}=4, n_{2}=5, n_{3}=6$ in the weak magnetic field $\mu_{B} H=0.02 K \quad J=1, J_{1}=12 K, J_{2}=8$, $g=2, g_{1}=0.5, g_{2}=3$. 


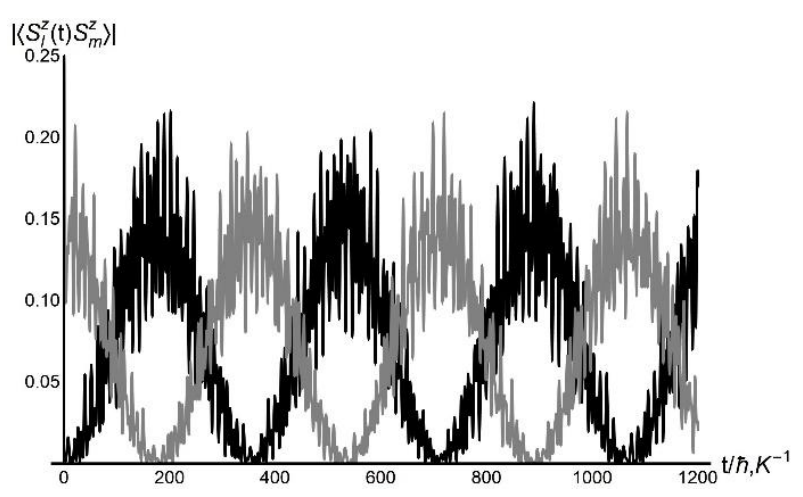

Fig. 5. Longitudinal dynamic pair correlation function $\left\langle S_{l}^{z}(t) S_{m}^{z}\right\rangle$ (black line) and autocorrelation function $\left\langle S_{l}^{z}(t) S_{l}^{z}\right\rangle$ (gray line) for the model with two distorted links for $\quad n_{1}=n_{3}=8, n_{2}=6, J=1 K, \quad J_{1}=J_{2}=2, H=0 \quad$ at $l=n_{1}=8, m=n_{1}+n_{2}+1=15$ and $l=m=8$, respectively.

\section{Summary and conclusions}

Two exactly solvable spin- $1 / 2$ models with XX exchange interactions with one and two distorted links and finite total number of spins are investigated analytically and numerically.

In particular, we obtained the dispersion equations for the stationary states with one inverted spin are derived, and the analytical relations for the critical values of model parameters which correspond to the appearance of the localized impurity levels. The low temperature thermodynamics of above models are studied numerically.

We found a complex character of the dependence of the heat capacity on applied longitudinal magnetic field with numerous minima and maxima.

The field dependence of z-projection of the average total spin and the field dependence of magnetization at zero temperatures have the finite jumps associated with the quasi-continuous spectrum, and the impurity levels. At rather low temperatures the remnants of these jumps are clearly visible. The average $z$-projection of the spins of distorted link(s) may decrease with the increasing of the magnetic field for some values of model parameters.

The temperature dependence of specific heat may demonstrate additional maxima at very low temperatures.

The pair dynamical correlation function and autocorrelation function also affected noticeably by the local levels, which results to the complex oscillations patterns. So, the finite nature of the models, and the appearance of the localized levels may effect noticeably on the local thermodynamic characteristics.

\section{References}

1. H.J Mikeska, A.K. Kolezhuk, One-Dimensional Magnetism - in "Quantum Magnetism", ed. by U.
Schollwöck, J. Richter, D.J.J. Farnell and R.F. Bishop, Lecture Notes in Physics, 645, 1 (2004)

2. A.A. Zvyagin, Finite Size Effects in Correlated Electron Models: Exact Results, Imperial College Press, London (2005).

3. A.A. Zvyagin, Quantum Theory of One-Dimensional Spin Systems, Cambridge Scientific Publishers, Cambridge (2010).

4. E. Lieb, J. Schults, and D. Mattis, Ann. Phys. 16, 407, (1961).

5. S.A. Pikin, V.M. Tsukernik, ZhETF, 50, 1377 (1966) [S.A. Pikin, V.M. Tsukernik, Soviet Physics JETP, 23, 915 (1966)]

6. V.Z. Kleyner, V.M. Tsukernik, FMM, 39, 947 (1975).

7. V.Z. Kleyner, V.M. Tsukernik, FMM, FNT 6, 332 (1980) [Low Temp. Phys. 6, 158 (1980)].

8. O. Derzhko, Condensed Matter Physics, 5, 729 (2002).

9. A.A. Zvyagin, Phys. Rev. B 97, 144412 (2018)

10. O. Derzhko and J. Richter, Phys. Rev. B 55, 14298 (1997).

11. E.V. Ezerskaya, A.A. Chovpan, FNT 32, 1213 (2006) [Low Temp. Phys. 32, 921 (2006)].

12. P.M. Duxbury, J. Oitmaa, M.N. Barber, A. van der Bilt, K.O. Joung, R.L. Carlin, Phys.Rev. B 24, 5149 (1981).

13. M. Kenzelmann, R. Coldea, D.A. Tennant, D. Visser, M. Hofmann, P. Smeibidl, Z. Tylczynski, Phys. Rev. B, 65, (2002).

14. P. Jordan and E. Wigner, Z. Phys. 47, 631 (1928). 